\title{
Outsourcing/Offshoring Insights Going Beyond Reshoring to Rightshoring
}

Tate, Wendy; Bals, Lydia

\author{
Document Version \\ Accepted author manuscript
}

Published in:

International Journal of Physical Distribution \& Logistics Management

DOI:

10.1108/IJPDLM-11-2016-0314

Publication date:

2017

License

Unspecified

Citation for published version (APA):

Tate, W., \& Bals, L. (2017). Outsourcing/Offshoring Insights: Going Beyond Reshoring to Rightshoring. International Journal of Physical Distribution \& Logistics Management, 47(2/3), 106-113.

https://doi.org/10.1108/IJPDLM-11-2016-0314

Link to publication in CBS Research Portal

\section{General rights}

Copyright and moral rights for the publications made accessible in the public portal are retained by the authors and/or other copyright owners and it is a condition of accessing publications that users recognise and abide by the legal requirements associated with these rights.

Take down policy

If you believe that this document breaches copyright please contact us (research.lib@cbs.dk) providing details, and we will remove access to the work immediately and investigate your claim. 


\section{Outsourcing/Offshoring Insights: Going Beyond Reshoring to Rightshoring}

\section{Wendy Tate and Lydia Bals}

Journal article (Accepted manuscript)

CITE: Tate, W., \& Bals, L. (2017). Outsourcing/Offshoring Insights: Going Beyond Reshoring to Rightshoring. International Journal of Physical Distribution \& Logistics Management, 47(2/3), 106-113.

DOI: 10.1108/IJPDLM-11-2016-0314

This article is [C Emerald Group Publishing and permission has been granted for this version to appear here: https://research.cbs.dk/en/publications/outsourcingoffshoring-insights-going-beyond-

reshoring-to-rightsho. Emerald does not grant permission for this article to be further copied/distributed or hosted elsewhere without the express permission from Emerald Group

Publishing Limited.

Uploaded to Research@CBS: December 2018 


\section{Outsourcing/offshoring insights: going beyond reshoring to rightshoring}

Wendy L. Tate, Ph.D., Associate Professor of Supply Chain Management, University of Tennessee, Email: Wendy.Tate@ utk.edu

and

Lydia Bals, Dr., Professor of Supply Chain \& Operations Management, University of Applied Sciences Mainz - School of Business; Visiting Professor Department of Strategic Management and Globalization, Copenhagen Business School, Email: 1ydia.bals@hs-mainz.de; lb.smg@cbs.dk

Please see final published version:

Tate, Wendy L., \& Bals, L. (2017): Outsourcing/offshoring insights: going beyond reshoring to rightshoring, International Journal of Physical Distribution and Logistics Management, Vol. 47, No. 2/3. 106-113. 


\section{Outsourcing/offshoring insights: going beyond reshoring to rightshoring}

\section{Structured Abstract:}

Purpose - The last decades have seen manufacturing and services offshoring on the rise, often motivated by low prices and without consideration of other important criteria such as additional cost measures and risk. With wages in former low-cost countries and automation/robotization increasing, these decisions are increasingly contested. Re-evaluations of "shoring" decisions inherently create a need to re-examine theoretical and academic contributions to this rapidly changing phenomenon. Therefore, the special issue sought manuscripts that added to the exciting and dynamic body of knowledge on "rightshoring."

Design/methodology/approach - The paper starts out by delimiting outsourcing/insourcing and offshoring/reshoring as part of a conceptual "rightshoring" framework to establish a common terminology and context for the insights gathered in the special issue. It illustrates that "shoring" options can be classified along geographical and governance dimensions.

Findings - Both the geographical and governance dimensions are part of the rightshoring decision which is an important conceptual foundation for this special issue, as it invited insightful pieces on all of these phenomena (e.g. outsourcing, insourcing, offshoring, reshoring), acknowledging that these decisions are embedded in the same context - firms making governance and location decisions. Therefore, papers 1-4 primarily focus on offshoring, whereas paper 5 focuses on insourcing and paper 6 on reshoring. Their main findings are summarized in Table 2.

Research limitations/implications - Suggestions for future research out of the 6 papers are summarized in Table III. There is ample opportunity to further shed light on these suggestions as well as to cover parts of the "rightshoring" framework presented, that remain less covered here (e.g. Insourcing and/or Reshoring).

Practical implications - The array of potential "rightshoring" options fosters clarity about the phenomena studied and their implications. The main practical implications of the 6 papers are summarized in Table II.

Originality/value -The overall conceptual framework highlights the positioning of the final papers included into the special issue and provides guidance to scholars and managers alike.

Keywords: Rightshoring, Offshoring, Reshoring, Insourcing, Outsourcing, Make or buy; Location; Governance 
The last decades have seen manufacturing and services offshored from industrialized countries to low labor cost regions like Asia. These geographic locational decisions were often made based on low price and ignored other important criteria such as additional cost measures and risk in the decision-making process (Tate et al., 2009; Bhatnagar et al., 2003). Because of increasing wages in typical low cost countries and other added complexity such as economic and supply chain risk, many well-known global organizations as well as smaller companies (Gray et al., 2013) are re-evaluating their supply chain designs (Tate et al., 2014; Christopher and Holweg, 2011). Also, continuously rising automation and robotization ("Internet of Things") with low or even without human intervention in industrialized countries (OECD, 2016) is driving many organizations to re-evaluate their "shoring" decisions from both a manufacturing and a supply perspective. Re-evaluations of "shoring" decisions inherently create a need to re-examine theoretical and academic contributions to this rapidly changing phenomenon. As special issue editors, the intent of this special issue was to nurture and develop manuscripts that add to the exciting and dynamic body of knowledge on "rightshoring."

According to the business press and related studies, $14 \%$ of companies have concrete plans to reshore to their home country in the near future (Hagerty, 2012) and 38\% are convinced that their direct competitors have already practiced reshoring activities, particularly in the United States (Tate et al., 2012). Another study reports that approximately every fourth to sixth formerly offshored activity is followed by a relocation to a domestic destination within the upcoming four years (Kinkel and Maloca, 2009). The reshoring trend is also reemphasized by the SCM World's Report 2015, that identifies a shift from manufacturing footprints from country-oriented (e.g. China) towards more regional models (O'Marah, 2015). All of these are very practical examples of a very real phenomenon. The idea being that manufacturing, service and sources of supply should be located in regions that help firms to better mitigate and manage risk!

Although the reversal of offshoring processes has been documented since the 1980s (Fratocchi, 2014), there has been a strong push in recent years - particularly in the U.S. - to reshore products and services, largely driven by a political platform to "bring jobs back home" (Tate, 2014). But there is also significant research performed in many other countries that relates to the location decision. In some cases, research focuses on bringing jobs back to high cost environments, that is an interesting take on the issue. Decision-makers weighing the relative benefits and the risks of offshoring, nearshoring or reshoring are finding that the most important aspect is to focus on "rightshoring". The call for papers for this special issue invited research on such "rightshoring" in a very broad sense: The various governance and geographic dimensions that are available to firms are synthesized in Figure 1. 


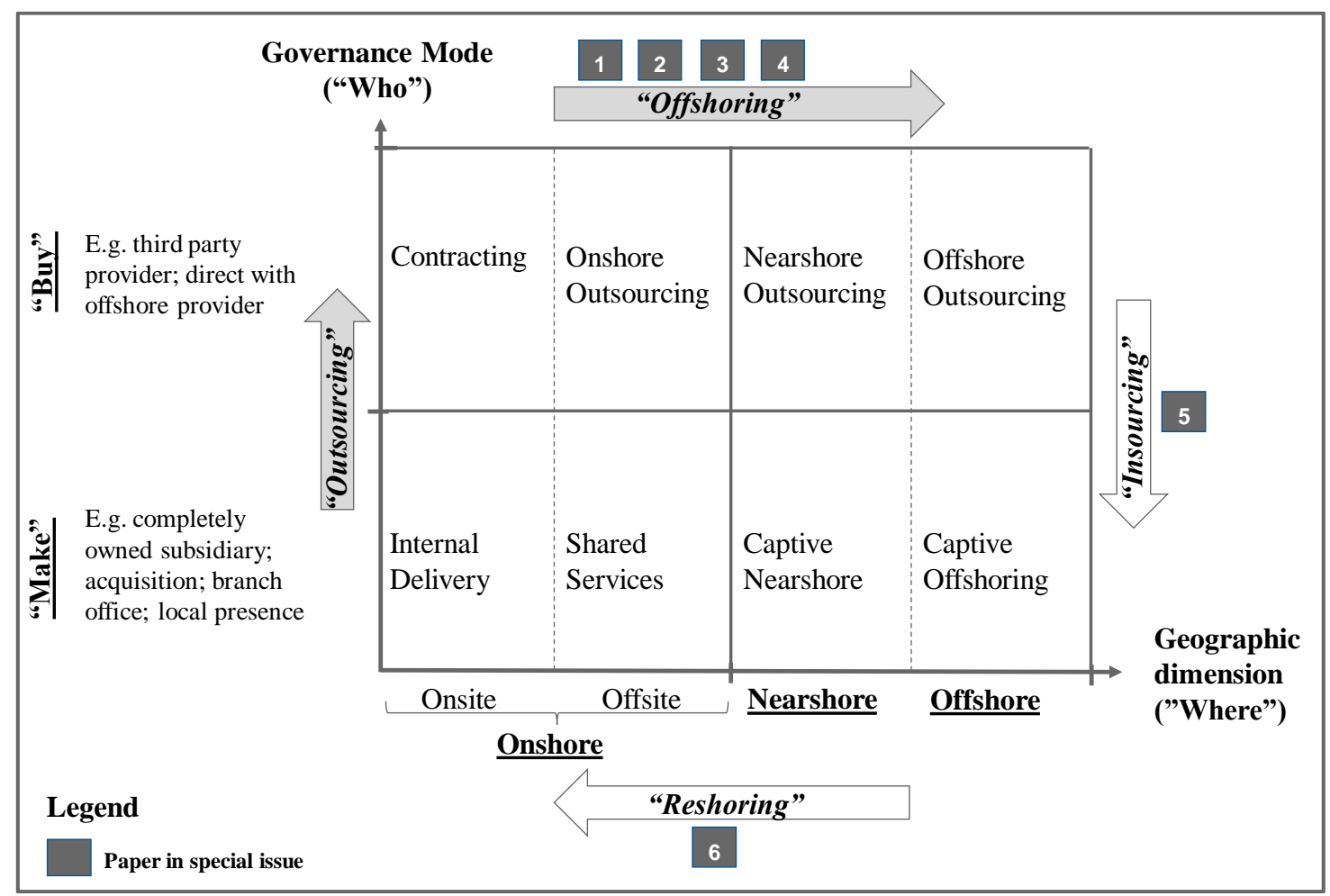

Figure 1 - The rightshoring decision options, adapted from: Jahns et al. (2006), Foerstl et al. (2016), Tate et al. (2016)

Figure 1 illustrates that "shoring" options can be classified along geographical and governance dimensions. Apart from opening the spectrum of potential areas of focus, this figure also helps to clarify that a "rightshoring" decision can, but does not necessarily have to, include an element of geographical shift. This fundamental assumption is supported by other scholars such as Gray et al. (2013), whose onshore or offshore dimension defines four available reshoring options: In-House Reshoring, Reshoring for Insourcing, Reshoring for Outsourcing, and Outsourced Reshoring. A full and more comprehensive array of such reverse options is also proposed in Foerstl et al. (2016). Thus, companies may consider the make or buy as well as the geographical dimension, but in the end stay domestic. While staying domestic they could still outsource an internal activity moving from a make to a buy. From an empirical perspective, this type of activity would look like an outsourcing decision, because the decision making might have included an analysis of the geographical side that concluded the "right" shore is actually domestic.

In line with Figure 1, offshoring (e.g. from the U.S. to the Philippines) involves international relocation of disaggregated firm value chain activities in governance modes that are captive, collaborative or outsourced (Bals et al., 2013; Contractor et al. 2010; Jahns et al., 2006; Kinkel and Maloca, 2009). In contrast, nearshoring involves relocating operations close to country borders (e.g. Canada and Mexico for the U.S.) that oftentimes lead to benefits arising from local trading alliances (e.g. NAFTA).

The arrows in Figure 1 also illustrate that while the grey arrows delimit outsourcing (governance, from make to buy) and offshoring (geography, from onsite towards offshore), the white arrows delimit the reverse movements of insourcing (governance, from buy to make) and reshoring (geography, from offshore to nearshore or onshore). That both areas are part of the rightshoring decision option is important to mention as this special issue invited insightful pieces on all of these phenomena, acknowledging that these decisions are embedded in the same context - firms making governance and location decisions. Therefore, the research topics invited ranged from determining the boundary of the firm and capability analysis (e.g. McIvor, 2010; Handley and Benton, 2012) to the disintegration at the former source/location, relocation and reintegration (e.g. Jensen et al., 2013), and respective contingencies for such decisions like cultural and 
geographic distance, decision magnitude or task/activity characteristics such as complexity (e.g. Bals et al., 2016; Foerstl et al., 2016; Bals et al., 2015). Research that looks at the decision making process across multiple firms, multiple functions, or across networks involving multiple organizations was invited to help broaden this knowledge base.

There was an encouraging response to the call for papers for this special issue with 30 submissions. The six papers ultimately accepted went through a rigorous process of review, with 3-5 review rounds. As guest editors we are excited to showcase what we consider to be some of the best research in this area to date. Table 1 provides a summary of the papers included in this special issue.

\begin{tabular}{|l|l|l|l|l|}
\hline$\#$ & Authors & $\begin{array}{l}\text { Main } \\
\text { Focus }\end{array}$ & Paper Title & Methodology \\
\hline 1 & $\begin{array}{l}\text { Lin, Tan and } \\
\text { Chen }\end{array}$ & Offshoring & $\begin{array}{l}\text { Global Offshoring Portfolio Diversity and } \\
\text { Performance Implications }\end{array}$ & $\begin{array}{l}\text { Empirical analysis (2004-2011, } \\
\text { 24 countries) using the ORN } \\
\text { database }\end{array}$ \\
\hline 2 & Brandl & Offshoring & $\begin{array}{l}\text { Direct and Indirect Value Creation in } \\
\text { Offshored Knowledge-Intensive Services } \\
\text { one conglomerate with three } \\
\text { offshored service production } \\
\text { processes }\end{array}$ \\
\hline 3 & $\begin{array}{l}\text { Presbitero, } \\
\text { Roxas and } \\
\text { Chadee }\end{array}$ & Offshoring & $\begin{array}{l}\text { Sustaining Innovation of Information } \\
\text { Technology Service Providers: Focus on } \\
\text { the Role of Organizational Collectivism }\end{array}$ & $\begin{array}{l}\text { Structural equation modelling } \\
\text { with data from a survey (n=388) } \\
\text { of IT Service Providers (ITSP) in } \\
\text { the Philippines }\end{array}$ \\
\hline 4 & $\begin{array}{l}\text { Paz-Aparicio, } \\
\text { Ricart and } \\
\text { Bonache }\end{array}$ & Offshoring & $\begin{array}{l}\text { Understanding the decision to offshore } \\
\text { human resources activities: A } \\
\text { coevolutionary perspective }\end{array}$ & $\begin{array}{l}\text { Empirical analysis using the ORN } \\
\text { database and descriptive case of a } \\
\text { multinational and its experience } \\
\text { with offshoring. }\end{array}$ \\
\hline 5 & $\begin{array}{l}\text { Hazen, } \\
\text { Hartman and } \\
\text { Ogden }\end{array}$ & Insourcing & $\begin{array}{l}\text { Bring it Back? An Examination of the } \\
\text { Insourcing Decision }\end{array}$ & $\begin{array}{l}\text { Case study involving data from } \\
\text { 12 firms in the manufacturing } \\
\text { industry with insourcing } \\
\text { experience }\end{array}$ \\
\hline 6 & $\begin{array}{l}\text { Moradlou, } \\
\text { Backhouse } \\
\text { and } \\
\text { Ranganathan }\end{array}$ & Reshoring & $\begin{array}{l}\text { Responsiveness, the Primary Reason } \\
\text { Behind Re-Shoring Manufacturing } \\
\text { Activities to the UK: An Indian Industry } \\
\text { Perspective }\end{array}$ & $\begin{array}{l}\text { Qualitative, interview-based } \\
\text { research in different industries } \\
\text { conducted in the UK and India }\end{array}$ \\
\hline
\end{tabular}

\section{Table 1 - The papers in the special issue}

As highlighted with the grey boxes in Figure 1 as well as in Table 1, papers 1-4 primarily focus on offshoring. First, Lin et al. provide an overarching perspective on the diversity of the global offshoring portfolio and its effects on performance implications. This more general perspective is followed by in-depth articles on specific aspects of offshoring. Brandl offers a study on direct and indirect value creation in offshored knowledge-intensive services. Presbitero et al. offer their insights on how Information Technology Service Providers (ITSPs) can leverage organizational collectivism to sustain innovation and Paz-Aparicio et al. provide a functional focus on the decision to offshore HR. The fifth paper by Hazen et al. examines insourcing choices in a manufacturing context, offering insights into the primary drivers behind such decisions. Finally, staying with the focus on drivers behind insourcing decisions, Moradlou et al examine reshoring, identifying major drivers such as a lack of responsiveness in the context of production reshoring from India to the UK.

One of the most important criteria for the special issue was that authors provide meaningful theoretical and managerial contributions. Table 2 provides a more detailed overview of each of the papers' main findings and contributions. 


\begin{tabular}{|c|c|c|c|}
\hline$\#$ & Main Findings & Practical Implications & Originality/value \\
\hline 1 & $\begin{array}{l}\text { - Location diversity shows a significant "flipped S-shape" relationship with } \\
\text { innovation outcomes, but has a negative impact on financial outcomes, } \\
\text { - Functional diversity has a significant and positive effect on innovation } \\
\text { outcome, } \\
\text { - The use of an outsourcing governance mode significantly moderates these } \\
\text { relationships }\end{array}$ & $\begin{array}{l}\text { - Firms may choose different offshoring portfolios } \\
\text { depending on its corporate strategy and both short and } \\
\text { long term priorities, } \\
\text { - A firm needs to align its offshoring decisions with the } \\
\text { strategic goal that the firm wishes to achieve through } \\
\text { offshoring, whether it is to improve innovation or financial } \\
\text { outcomes }\end{array}$ & $\begin{array}{l}\text { Firms which strategically coordinate all three } \\
\text { dimensions of their offshoring portfolio are } \\
\text { more likely to achieve better innovation or } \\
\text { financial outcomes from their use of } \\
\text { offshoring }\end{array}$ \\
\hline 2 & $\begin{array}{l}\text { There is direct value creation for the client and the service provider towards } \\
\text { the end of the production processes and additional indirect value creation in } \\
\text { various production stages, } \\
\text { - Indirect value is reflected in enhanced understanding of problems and their } \\
\text { own operations for the client and increased knowledge about clients and } \\
\text { problem-solving approaches for the service provider }\end{array}$ & $\begin{array}{l}\text { - Insights on the value creation logic of offshored services } \\
\text { and the value created beyond that logic, } \\
\text { - Details of various values and benefits of service } \\
\text { offshoring for client firms } \\
\text { Offers a focused perspective on value creation for service } \\
\text { provider firms in their own service production that can } \\
\text { lead to competitive advantages }\end{array}$ & $\begin{array}{l}\text { The paper is novel through its approach to } \\
\text { study offshoring from a value creation logic } \\
\text { perspective, including not only the client but } \\
\text { also the service provider perspective; it applies } \\
\text { a service production process perspective that is } \\
\text { novel in offshoring literature }\end{array}$ \\
\hline 3 & $\begin{array}{l}\text { - Knowledge sharing capability is positively related to innovation and } \\
\text { organizational learning capability fully mediates the effects of knowledge } \\
\text { sharing on innovation, } \\
\text { - Organizational collectivism is found to significantly and positively moderate } \\
\text { the effects of knowledge sharing on both organizational learning and } \\
\text { innovation, } \\
\text { - Organizational learning serves as the mechanism that transforms knowledge } \\
\text { into innovation, but this effect is contingent on organizational collectivism } \\
\text { of ITSPs }\end{array}$ & $\begin{array}{l}\text { - ITSPs from developing countries can look beyond costly } \\
\text { investments in research and development activities to } \\
\text { invigorate their innovative capabilities, } \\
\text { - ITSPs can focus on the development of their intangible } \\
\text { assets such as organizational collectivism to enhance the } \\
\text { effects of knowledge-based resources on innovation for } \\
\text { sustaining their competitiveness }\end{array}$ & $\begin{array}{l}\text { The moderated-mediation analytical approach } \\
\text { to assessing the joint effects of knowledge } \\
\text { sharing, organisational learning and } \\
\text { collectivism on innovation is novel }\end{array}$ \\
\hline 4 & $\begin{array}{l}\text { - A coevolutionary model is proposed for understanding the behaviour of } \\
\text { companies offshoring their HR activities. } \\
\text { - This study contends that companies should address their decision to offshore } \\
\text { HR activities from a dynamic perspective, being aware of three processes } \\
\text { that are in constant change: the evolution of the HR function, the evolution } \\
\text { of service providers, and the evolution of offshoring decisions }\end{array}$ & $\begin{array}{l}\text { - Decisions should consider the costs and benefits of both } \\
\text { outsourcing and offshoring simultaneously, taking into } \\
\text { account the company's stage in the evolution of the HR } \\
\text { function, the experience of governing and coordinating } \\
\text { offshore activities, and the experience of the potential } \\
\text { service providers }\end{array}$ & $\begin{array}{l}\text { The coevolutionary multidisciplinary model of } \\
\text { HR offshoring seeks to make a threefold } \\
\text { contribution to the international business, } \\
\text { strategy and human resource management } \\
\text { disciplines }\end{array}$ \\
\hline 5 & $\begin{array}{l}\text { - Primary drivers for insourcing were predominantly the same as those cited } \\
\text { for outsourcing, } \\
\text { - Insourcing decisions are often made in response to a specific external trigger } \\
\text { event and not necessarily in concert with long-term, strategic goals; this is in } \\
\text { contrast to firms' desires to make more strategic location decisions, } \\
\text { - Insourcing/ outsourcing location decisions require continuous evaluation in } \\
\text { order to optimize competitiveness and align with long-term firm goals }\end{array}$ & $\begin{array}{l}\text { - Provides insights for supply chain, logistics and operations } \\
\text { management professionals who seek to better understand } \\
\text { the critical factors that should be considered when } \\
\text { deciding whether or not to insource }\end{array}$ & $\begin{array}{l}\text { The benefits of insourcing are being } \\
\text { considered to a greater extent across industry, } \\
\text { yet there is a dearth of academic or practitioner } \\
\text { literature that business leaders and } \\
\text { academicians can use as the basis for } \\
\text { examining this decision; this research provides } \\
\text { both the basis and motivation for developing } \\
\text { knowledge in this area of increasing } \\
\text { importance }\end{array}$ \\
\hline 6 & $\begin{array}{l}\text { - Re-shoring to the UK is the result of inadequacy in responsiveness and long } \\
\text { production lead-times of the Indian suppliers, } \\
\text { - Top factors behind this inadequacy in responsiveness are logistics and } \\
\text { transportation, electricity shortage, excessive paperwork and working } \\
\text { attitude }\end{array}$ & $\begin{array}{l}\text { - The identified drivers offer areas for improvement for the } \\
\text { Indian industry to enhance its competitiveness. }\end{array}$ & $\begin{array}{l}\text { This paper aims to fill a gap in the re-shoring } \\
\text { literature by providing a clear picture behind } \\
\text { the reasons for re-shoring in the UK and } \\
\text { identifies the drivers in the component supply } \\
\text { from India }\end{array}$ \\
\hline
\end{tabular}

Table 2 - Focus areas and main findings 
The papers in this special issue also underline substantial opportunities for additional research on rightshoring. Many companies still make many decisions that are largely based on price or low labor costs. However, there are many additional cost factors and functional areas that could also be involved in the decision making process that determines where in the world firms should make or buy their products and/or services. Moreover, in many cases, "institutional pressure" be it mimetic, normative or coercive, influences firms' decisions. Unfortunately, such decisions tend not to take all the pertinent "facts" into account. In terms of specific suggestions for future research, the six papers provide the suggestions highlighted in Table 3.

\begin{tabular}{|c|c|}
\hline$\#$ & Suggestions for Future Research \\
\hline 1 & $\begin{array}{l}\text { Future research could examine how integration of the offshored functions and integration with domestically located } \\
\text { functions affect innovation outcomes } \\
\text { Future research could delve deeper into the organizational costs involved with different offshoring governance } \\
\text { modes and how this affects offshoring innovation outcomes } \\
\text { - Future research could examine firms with more offshoring projects and longer experience of offshoring to see if the } \\
\text { results still hold }\end{array}$ \\
\hline 2 & $\begin{array}{l}\text { - Future research could study the production process of diverse services in more detail } \\
\text { - Future research should continue taking a production process perspective, which also allows reshoring-influenced } \\
\text { changes in production processes to be identified, for example; such a perspective goes beyond cost or resource } \\
\text { considerations, applying theories on transaction-cost economics }\end{array}$ \\
\hline 3 & $\begin{array}{l}\text { Future research could analyze collectivism at both societal and organizational levels, by collecting data on } \\
\text { collectivism not only at the organizational level but also at the country level; this would allow multi-level analysis, } \\
\text { which can demonstrate whether collectivism at the organizational level is primarily influenced by collectivism at the } \\
\text { country level } \\
\text { - Future research should undertake investigations of ITSPs in developing countries, such as in India or China which } \\
\text { also have a growing ITSP sector; results for these countries could be compared with the results obtained for the } \\
\text { Philippines (i.e. cross-country comparison), enabling generalisability of results across ITSPs in developing countries } \\
\text { - Instead of perceptual measures of organizational capabilities and characteristics, future research could use actual } \\
\text { measures (e.g. innovation can be measured in terms of number of products and services that have been improved or } \\
\text { newly developed) to be able to demonstrate greater reliability and validity of results } \\
\text { - To the extent that the performance of ITSPs and their clients are intertwined, future research should also consider } \\
\text { the role of clients in influencing innovation of ITSPs }\end{array}$ \\
\hline 4 & $\begin{array}{l}\text { - Future research should integrate processes from multiple disciplines, so that theoretical understanding can be } \\
\text { elevated from basic contractual and resource-dependent perspectives towards multidisciplinary models }\end{array}$ \\
\hline 5 & $\begin{array}{l}\text { Future research should examine mechanisms through which firms can allay short-term problems while focusing } \\
\text { ultimately on long-term solutions } \\
\text { - Other industries and locations should also be investigated to substantiate the findings of this research or to document } \\
\text { and understand situations where they may not apply } \\
\text { - Future research projects should consider the effects of other factors such as the firm's primary manufacturing focus } \\
\text { (e.g. final products, subassemblies or components), firm size, duration of the outsourced manufacturing strategy and } \\
\text { the outsourced provider's location } \\
\text { - Comparing and contrasting insourcing of domestically versus internationally outsourced functions can be a fruitful } \\
\text { area for future research as well }\end{array}$ \\
\hline 6 & $\begin{array}{l}\text { - The findings of the paper need further in-depth investigation and identification of other factors behind re-shoring, } \\
\text { e.g. a more quantitative approach and larger sample sizes to include a wider range of industrial sectors are required } \\
\text { - It should be noted that responsiveness was found to be the main reason for re-shoring to UK only in the context of } \\
\text { Indian industries, this can be further supported by studying other low cost countries such as China }\end{array}$ \\
\hline
\end{tabular}

Table 3 - Future research suggestions

The "rightshoring" decision making process impacts all businesses across the world. Thus, even before publication, the interest in this special issue by prospective authors and other researchers has been considerable. Our hope as guest editors is that this special issue can provide helpful insights and also ways to move research about the rightshoring decision forward (including offshoring/reshoring, outsourcing/insourcing). Guest editing this special issue has been a great experience. We would like to thank the authors, the reviewers, Alex Ellinger and IJPDLM's editorial administrator, Lauren Kiser for their thoroughness and thoughtfulness throughout this process. 
Respectfully,

Wendy Tate and Lydia Bals

\section{REFERENCES}

Bals, L., Daum A. and Tate W.L. (2015), "From offshoring to rightshoring: Focus on the backshoring phenomenon", AIB Insights, Vol. 15 No. 4, pp. 3-8

Bals, L., Jensen, P.D.Ø., Larsen, M.M. and Pedersen, T. (2013), Exploring Layers of Complexity in Offshoring Research and Practice. In T. Pedersen, L. Bals, P.D.Ø. Jensen and M.M. Larsen (Eds.), The Offshoring Challenge: Strategic Design and Innovation for Tomorrow's Organization, pp. 1-18, Springer, London.

Bals, L., Kirchoff, J. and Foerstl, K. (2016), "Exploring the Reshoring and Insourcing Decision Making Process: Toward an Agenda for Future Research", Operations Management Research, Vol. 9 No. 3-4, pp. 102-116.

Bhatnagar, R., Jayaram, J., and Phua, Y. C. (2003), "Relative importance of plant location factors: a cross national comparison between Singapore and Malaysia", Journal of Business Logistics, Vol. 24 No. 1, pp. 147-170.

Christopher, M. and Holweg, M. (2011), "Supply Chain 2.0": managing supply chains in the era of turbulence". International Journal of Physical Distribution \& Logistics Management, Vol. 41 No. 1, pp. 63-82.

Contractor, F.J., Kumar, V., Kundu, S.K. and Pedersen, T. (2010), "Reconceptualizing the firm in a world of outsourcing and offshoring: The organizational and geographical relocation of high- value company functions", Journal of Management Studies, Vol. 47 No. 8, pp. 1417-1433.

Foerstl, K., Kirchoff, J. and Bals, L. (2016), "Reshoring and Insourcing: Drivers and Future Research Directions", International Journal of Physical Distribution and Logistics Management, Vol. 46 No. 5, pp. 492-515. Nominated for AOM Carolyn Dexter (Best International Paper) award 2015.

Fratocchi, L., Di Mauro, C., Barbieri, P., Nassimbeni, G. and Zanoni, A. (2014), "When manufacturing moves back: Concepts and questions", Journal of Purchasing and Supply Management, Vol. 20 No. 1, pp. 54-59.

Gray, J.V., Skowronski, K., Esenduran, G. and Johnny Rungtusanatham, M. (2013), "The reshoring phenomenon: what supply chain academics ought to know and should do", Journal of Supply Chain Management, Vol. 49 No. 2, pp. 27-33.

Hagerty, J.R. (2012, July 18th), "Some firms opt to bring manufacturing back to U.S.", Wall Street Journal, http://www.wsj.com/articles/SB10001424052702303612804577533232044873766 (accessed October 17th, 2016).

Handley, S.M. and Benton, W.C. (2012), "The influence of exchange hazards and power on opportunism in outsourcing relationships", Journal of Operations Management, Vol. 30 No. 1, pp. 55-68.

Jahns, C., Hartmann, E. and Bals, L. (2006), "Offshoring: Dimensions and diffusion of a new business concept", Journal of Purchasing and Supply Management, Vol. 12 No. 4, pp. 218-231.

Jensen P.D.Ø., Larsen, M.M. and Pedersen, T. (2013), "The organizational design of offshoring: Taking stock and moving forward", Journal of International Management, Vol. 19 No. 4, pp. 315-323.

Kinkel, S. and Maloca, S. (2009), "Drivers and antecedents of manufacturing offshoring and backshoring-A German perspective”, Journal of Purchasing and Supply Management, Vol. 15 No. 3, pp. 154-165.

McIvor, R. (2010), “Global services outsourcing”, Cambridge University Press, Cambridge.

OECD [Organisation for Economic Co-operation and Development] (2016a). Working Party on Communication Infrastructures and Services Policy: The internet of things: Seizing the benefits and addressing the challenges, http://www.oecd.org/officialdocuments/publicdisplaydocumentpdf/?cote=DSTI/ICCP/CISP(2015 3/FINAL\&docLanguage=En (accessed October 17th, 2016).

O’Marah, K. (2015), "Future of Supply Chain: Report 2015”, SCM World.

Tate, W.L. (2014), "Offshoring and reshoring: U.S. insights and research challenges", Journal of Purchasing and Supply Management, Vol. 20 No. 1, pp. 66-68. 
Tate, W.L., Fawcett, S., Schoenherr, T., Ashenbaum, B., Carter, C., \& Bals, L. (2016). Purchasing \& Supply Management: Enhancing Competitiveness and Customer Value, My Educator, LLC, Orem, UT.

Tate, W.L., Ellram, L.M., Schoenherr, T. and Petersen, K.J. (2014), "Global competitive conditions driving the manufacturing location decision”, Business Horizons, Vol. 57 No. 3, pp. 381-390.

Tate, W.L., Ellram, L.M., Petersen, K.J. and Schoenherr, T. (2012), "Offshoring and reshoring: A survey of current practices". Council of Supply Chain Management Professionals, Oakbrook.

Tate, W.L., Ellram, L.M., Bals, L. and Hartmann, E. (2009), "Offshore outsourcing of services: An evolutionary perspective", International Journal of Production Economics, Vol. 120 No. 2, pp. 512-524. 